SHORT REPORTS

\section{Membranous glomerulonephritis, dermatomyositis, and bronchial carcinoma}

Membranous glomerulonephritis is associated with malignant disease in about $10 \%$ of cases. ${ }^{1}$ The prevalence of neoplasia in patients with dermatomyositis is estimated at $15-20 \%$ in those aged over $45 .{ }^{2}$ The occurrence of membranous glomerulonephritis with dermatomyositis is extremely unusual and in the one documented case malignancy was not implicated. ${ }^{3}$

\section{Case report}

A woman aged 58 years presented with ankle swelling and proteinuria. She smoked 20-30 cigarettes a day, was taking no medication, and was normotensive. Urine microscopy showed red cells with granular and cellular casts. The proteinuria was selective and amounted to $5 \cdot 2 \mathrm{~g} / 24 \mathrm{~h}$. Serum concentrations were as follows: albumin $25 \mathrm{~g} / 1$, urea $6.8 \mathrm{mmol} / 1(41 \mathrm{mg} / 100 \mathrm{ml})$ and creatinine $129 \mu \mathrm{mol} / 1(1.46 \mathrm{mg} / 100 \mathrm{ml})$, ESR $50 \mathrm{~mm}$ in $1 \mathrm{~h}$, and C3 1.28 $\mathrm{U}(0 \cdot 8-1 \cdot 4)$. A renal biopsy specimen showed diffuse capillary loop thickening and basement membrane spikes (figure). Immunofluorescence showed granular

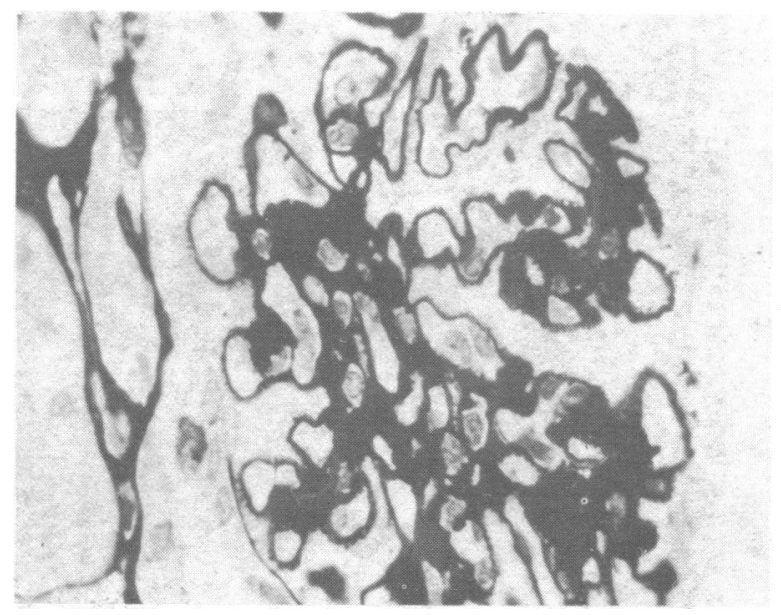

Renal glomerulus showing basement membrane spikes. Silver stain $\times 350$ (original magnification ).

IgG deposition along capillary loops. The features were typical of membranous glomerulonephritis. Treatment with frusemide was started.

Three years later she developed dermatomyositis with periorbital oedema; dusky erythema of the face, trunk, and hands; proximal muscle weakness; and dysphagia. The serum concentration of creatinine phosphokinase was $290 \mathrm{U} / 1(10-60)$, aldolase $3.6 \mathrm{U} / 1(0.5-3.0)$, and lactate dehydrogenase 760 $\mathrm{U} / 1$ (50-220). The proteinuria had diminished to $0.7 \mathrm{~g} / 24 \mathrm{~h}$, and serum concentration of albumin was $29 \mathrm{~g} / 1$, urea $9 \mathrm{mmol} / 1(54 \mathrm{mg} / 100 \mathrm{ml})$, creatinine $105 \mu \mathrm{mol} / 1(1.1 \mathrm{mg} / 100 \mathrm{ml})$, and ESR $60 \mathrm{~mm}$ in $1 \mathrm{~h}$. Antinuclear antibody was not detected. A chest radiograph was normal but lung tomography showed a $1-\mathrm{cm}$ opacity in the right mid-zone. An oat cell tumour was later resected with the upper lobe. Preoperative treatment with prednisone and azathioprine dramatically improved the dermatomyositis and this improvement was sustained when the drugs were stopped postoperatively.

\section{Comment}

The presence of both membranous glomerulonephritis and dermatomyositis in a cigarette smoker strongly suggested an underlying malignancy. Membranous nephropathy is thought to be an immune complex disease. The renal lesion in this patient may have resulted from the deposition of immune complexes induced by the tumour. ${ }^{1}$ Circulating immune complexes tend to be found early in the course of malignant disease and an associated nephropathy may precede the discovery of a tumour by over one year. ${ }^{4}$ Although the pathogenesis of dermatomyositis is not clear, the link with cancer may provide a clue. This association perhaps results from an immune response to tumour antigen which cross-reacts with muscle. Both humoral and cell-mediated mechanisms may participate. ${ }^{5}$ In our patient the nephropathy had already improved when the dermatomyositis first appeared. If both conditions were precipitated by tumour antigen this disparity in time course suggests that their pathogenic mechanisms differ.

I would like to thank Dr J S Comaish for permission to publish this case, Dr M G C Dahl and Dr M Ward for helpful criticism, and Dr A Morley for the photomicrograph.

1 Row, P G, et al, Quarterly fournal of Medicine, 1975, 44, 207.

2 Bohan, A, et al, Medicine (Baltimore), 1977, 56, 255.

3 Fukui, H, et al, fapanese fournal of Nephrology, 1976, 18, 523.

${ }^{4}$ Eagen, J W, and Lewis, E J, Kidney International, 1977, 11, 297.

5 Pearson, C M, and Bohan, A, Medical Clinics of North America, 1977, $61,439$.

(Accepted 5 fuly 1979)

Royal Victoria Infirmary, Newcastle upon Tyne NE1 4LP

JOHN D G ROSE, MB, MRCP, senior house officer in dermatology

\section{Current trends in contraception}

Recent evidence ${ }^{12}$ of mortality and morbidity among women taking oral contraceptives has been widely and often sensationally reported in the press. Fortunately this was countered by the clear, balanced recommendations of the presidents of the Royal College of General Practitioners and the Royal College of Obstetricians and Gynaecologists. $^{3}$ To assess the impact of these developments we analysed the contraceptive trends over the last four years in a large family planning clinic in our area.

\section{Methods and results}

The Palatine Centre is the largest family planning clinic in the Manchester area, with 11000 first-visit patients and a total of 26000 consultations each year. The contraceptive trends during the years 1975-8 inclusive, which covered the relevant period, were analysed. The age grouping of first-visit patients each year (table) shows a fairly constant distribution with only $8 \%$ aged over 35 . There was a small decrease, from $21 \%$ to $17 \%$, in patients aged under 20 seeking contraceptive advice. The figures for the contraceptive method being used by patients at their first visit in each year clearly show a trend away from the pill (from $83 \%$ to $73 \%$ ) over the four years, with a corresponding move towards the IUCD ( $6 \%$ to $9 \%$ ), cap ( $5 \%$ to $8 \%$ ), and condom ( $3 \%$ to $5 \%$ ), which is statistically significant with such large figures. During 1977 this trend appears to have accelerated. The IUCD and cap seem to have substantially taken up the ex-pill users. Additionally there has been a steady increase each year in condom users.

Ages of first-visit patients and their contraceptive methods

\begin{tabular}{|c|c|c|c|c|c|c|c|c|}
\hline \multirow[b]{2}{*}{ Year } & \multirow{2}{*}{$\begin{array}{r}\text { No aged } \\
\text { under } 20 \\
\end{array}$} & \multirow{2}{*}{$\begin{array}{c}\text { No aged } \\
20-35\end{array}$} & \multirow{2}{*}{$\begin{array}{l}\text { No aged } \\
\text { over } 35\end{array}$} & \multirow{2}{*}{$\begin{array}{c}\text { Total } \\
\text { patients }\end{array}$} & \multicolumn{4}{|c|}{ Contraceptive method } \\
\hline & & & & & Oral & IUCD & Cap & Condom \\
\hline $\begin{array}{l}1975 \\
1976 \\
1977 \\
1978\end{array}$ & $\begin{array}{l}2407 \\
2454 \\
2235 \\
1951\end{array}$ & $\begin{array}{l}7980 \\
8420 \\
8637 \\
8514\end{array}$ & $\begin{array}{l}875 \\
953 \\
909 \\
923\end{array}$ & $\begin{array}{ll}11 & 338 \\
11 & 827 \\
11 & 781 \\
11 & 388\end{array}$ & $\begin{array}{l}9374 \\
9481 \\
9368 \\
8363\end{array}$ & $\begin{array}{r}697 \\
817 \\
895 \\
1050\end{array}$ & $\begin{array}{l}561 \\
702 \\
764 \\
942\end{array}$ & $\begin{array}{l}320 \\
381 \\
439 \\
548\end{array}$ \\
\hline
\end{tabular}

\section{Discussion}

This trend away from the pill corresponds to that found in a similar study in the United States, ${ }^{4}$ although that reported figures only up to 1976. The major move away from the pill occurred in the subsequent two years in our study. Furthermore, the American report showed a small decrease in the use of the IUCD, which did not occur in Manchester. The significant movement away from the use of hormonal contraceptives in this group of women, most of whom were below the age of 